\author{
돼지 5품종에 있어서 mtDNA ND2 유전자의 \\ 선택적 개시코돈의 특성과 빈도 \\ 한상현* · 조인철* · 최유림* . 이종언* · 고문석* · 김재환** . 서보영** . 이정규** . 전진태** \\ 농촌진흥청 난지농업연구소*, 경상대학교 응용생명과학부**

\section{Characteristics and Frequencies of Alternative Initiation Codon(AIC) of mtDNA ND2 in Five Pig Breeds}

S. H. Han*, I. C. Cho*, Y. L. Choi*, C. E. Lee*, M. S. Ko*, J. H. Kim**, B. Y. Seo**,

J. G. Lee** and J. T. Jeon**

National Institute of Subtropical Agriculture, R.D.A.*,

Division of Applied Life Science, Gyeongsang National University**

\begin{abstract}
Alternative initiation codon(AIC) has been reported in the mitochondrial genes in various mammalian species. We investigated the AIC of mitochondrial NADH dehydrogenase 2 gene(mtDNA ND2) in five pig breeds. Two kinds of initiation codons(ATA/ATT) showing different frequencies among tested pig breeds were used. While all Large White pigs had ATA as an initiator methionine codon, all Landrace pigs had ATT. The other breeds(Berkshire, Duroc and Hampshire) had both initiation codons with the ATA frequencies, 91.9, 21.3 and $60.0 \%$, respectively. In the previous reports, all Chinese indigenous pig breeds were identified to have unique initiation codon ATA. Although the effect of AIC on the translation of mtDNA ND2 has not been studied in this study, AIC patterns in mtDNA ND2 will contribute to the maternity test using molecular markers in pig breeding.
\end{abstract}

(Key words : Alternative initiation codon, mtDNA, ND2, Breed-specific, Maternity test)

$$
\text { I 서 론 }
$$

가축돼지는 기원전 $6,000 ~ 9,000$ 년경 아시아 와 유럽에서 독립적으로 가축화 되어졌고, 이후 18 19세기 초에 중국 돼지들이 유럽에 전파되 어 돼지 육종과정에 유입된 것으로 보고 있다 (Bökönyi, 1974; Watanabe 등 1985; Jones, 1998).

포유동물의 미토콘드리아 DNA는 환상(circular) 의 이중나선 DNA로 길이는 약 $16 \sim 17.5 \mathrm{~kb}$ 정 도이며, 2 종류의 ribosomal RNA 유전자, 13 종 류의 peptide coding gene, 22 종류의 transfer
RNA유전자와 조절영역인 D-loop으로 구성되어 있다(Anderson 등, 1981; Lin 등, 1999). mtDNA 의 모계유전 특징과 핵 DNA에 비해 10배 이상 빠른 염기치환율을 보이기 때문에 DNA 다형성 에 근거한 종간 유연관계 분석과 진화과정 중 모계의 이동경로를 추적하는 좋은 자료가 되고 있다(Brown 등, 1979; Giles 등, 1980; Cann 등, 1984; Wilson 등, 1985; Kijas and Andersson, 2001).

현재까지 돼지 미토콘드리아 DNA 서열에 대 한 연구 자료들은 다양한 가축돼지 품종들의

Corresponding author : J. T. Jeon, Division of Applied Life Science, Department of Animal Science, Gyeongsang National University, Jinju 660-701, Gyeongnam, Korea. Tel : 055-751-5516, Fax : 055-756-7171, E-mail : jtjeon@nongae.gsnu.ac.kr 
기원과 유래 등을 설명하는 분자생물학적 정보 들을 제공하였다. Kijas 등(1998)과 Giuffra 등 (2000)은 돼지 MC1R 유전자에 대한 대립인자 형에 대한 분석을 통하여 품종에서 나타나는 특이적인 모색을 설명하였다. 또한, 조절부위인 D-loop과 12S 리보솜 RNA 유전자, cytochrome $\mathrm{B}$ 유전자 등의 다형성과 haplotype에 관한 연구 들은 가축돼지 형성과정과 진화, 중국돼지의 유럽 유입에 대한 분자적 증거들을 제시하였다 (Okumura 등, 1996; Giuffra 등, 2000; Kim 등, 2002; Alves 등, 2003; Watanobe 등, 2004). 돼지 mtDNA의 전체서열은 Ursing과 Arnason(1998)에 의해 최초로 보고된 후 현재까지 Landrace, Duroc, Large White, 유럽산 멧돼지, 중국재래돼 지 17 품종의 서열들이 밝혀졌으며, 이를 바탕 으로 돼지의 가축화 시기와 품종간 유연관계가 재조명되었다(Lin 등, 1999; Kijas과 Andersson, 2001; Yang 등, 2003).

돼지 mtDNA의 $\mathrm{ND} 2$ 유전자는 $\mathrm{H}$-strand 상에 위치하며 1,044-bp으로 구성되고 347 개의 아미 노산으로 이루어진 $\mathrm{NADH}$ dehydrogenase subunit 2를 암호화하고 있다. 현재까지 포유류를 중심으로 한 $\mathrm{mtDNA}$ 서열 연구보고에 따르 면, $N D 2$ 의 개시코돈(initiation codon)은 기존 의 단백질 해독과정과는 달리 선택적 개시코 돈(alternative initiation codon: AIC)을 갖는 것으 로 보고되었다(Ursing과 Arnason, 1998).

대부분의 미토콘드리아 단백질에서는 methionine 개시코돈으로 $\mathrm{ATG}$ 를 이용하지만 ND2에서 ATA 또는 ATT(isoleucine), ND4L에서는 GTG (valine)가 개시코돈의 역할을 하는 것으로 보고 되었다. 특히, $\mathrm{ND} 2$ 의 개시코돈의 경우 영장류를 비롯한 고래류, 설치류에서도 ATT가 보고되었 다(Janke 등, 2002; Arnason 등, 1993; Coble 등, 2004). 또한 고양이의 경우는 ATC(isoleucine) 서열이 보고되기도 하였다(Lopez 등, 1996). 돼 지의 경우 Lin 등(1999)과 Kijas와 Andersson (2001)은 Landrace과 스웨덴 멧돼지에서 개시코 돈으로 ATT, Yang 등(2003)은 중국재래돼지와 Large White에서 ATA, Duroc에서는 ATT 서열 을 보고하였다.

기존에 보고에 따르면 돼지 mtDNA $N D 2$ 의
개시코돈 서열은 ATT와 ATA 두 가지 서열이 출현하는 것으로 알려져 있으나, 현재까지 이 들 서열의 품종 특이성이나 다형성에 대한 체 계적인 연구는 보고되지 않았다. 따라서 $N D 2$ 의 개시코돈 서열을 가축돼지품종 집단에서 분석 하여 개시코돈 유전자 서열의 품종별 특이성 여부와 모계선조의 진화과정을 조사하기 위하 여 본 연구를 수행하였다.

\section{재료 및 방법}

\section{1. 공시동물 및 DNA 추출}

실험에 공시된 돼지는 농촌진흥청 난지농업연 구소에서 사육되고 있는 Landrace 40두, Large White 76두, Duroc 47두와 제주도 B종돈장과 종축개량협회에서 제공받은 Berkshire 62두, Hampshire 10두 등 5품종 235두를 공시하였다. Genomic DNA의 추출은 혈액에서 백혈구를 회 수하여 Miller 등(1988)의 방법을 변형하여 수행 하였다. 추출한 DNA는 RNase(Sigma, USA)와 proteinase K(Promega, USA)를 처리한 후 phenol extraction과 ethanol 침전법으로 정제하였으며, PCR 주형으로 이용하였다.

\section{2. $\mathrm{PCR}$ 증폭}

mtDNA ND2의 개시코돈이 포함된 영역을 증 폭하기 위하여 기존에 보고된 돼지 mtDNA 서 열(Genbank accession number: NC_000845)을 이 용하여 primer를 고안하였다. PCR 증폭에 이용 한 primer의 서열은 다음과 같다.

5008F: 5'-ACA TTC TAC AgT AAg gTC Ag-3' 5245R: 5'-TgT ggC TCg Tgg gTT AAA AT-3'

PCR 반응은 $10 \mathrm{x}$ reaction buffer, $0.2 \mathrm{mM}$ 의 $\mathrm{dNTP}, 15$ pmols의 forward와 reverse primer 및 3 units의 Taq DNA polymerase에 $100 \mathrm{ng}$ genomic DNA와 멸균된 탈이온수를 첨가하여 최

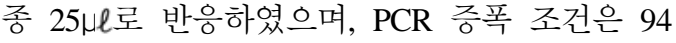
${ }^{\circ} \mathrm{C}$ 에서 2분간 pre-denaturation을 실시하고 $94{ }^{\circ} \mathrm{C}$ 에서 1 분, $55{ }^{\circ} \mathrm{C}$ 에서 1 분, $72{ }^{\circ} \mathrm{C}$ 에서 1 분을 $1 \mathrm{cy}$ - 
cle로 하여 총 30 cycle을 수행한 후 $72{ }^{\circ} \mathrm{C}$ 에서 10 분간 extension을 실시 후 $4{ }^{\circ} \mathrm{C}$ 에서 보관하였 다. PCR 산물은 $1 \%$ agarose gel 상에서 전기영 동 확인 후, Gel Extraction Kit(Qiagen, USA)를 이용하여 정제하고, 제한효소 절단과 $\mathrm{DNA}$ sequencing을 위한 cloning에 이용하였다.

\section{DNA sequencing}

$N D 2$ 의 개시코돈 및 서열의 확인을 위해 염 기서열분석을 실시하였다. 정제한 PCR 산물을 TOPO TA Cloning Kit(Invitrogen, USA)의 pCR2.1 plasmid vector에 연결하여 E. coli competent cell에 형질전환 시켰다. Plasmid는 WizardPlus SV Minipreps(Promega, USA)를 이용하여 분리하였 다. 염기서열의 분석은 $\mathrm{ALF}^{\mathrm{TM}} \mathrm{Cy} 5^{\mathrm{TM}}$ AutoCycle DNA Sequencing Kit(Pharmacia Biotech, Sweden) 으로 반응한 후 ALFexpress(Pharmacia Biotech, Sweden)를 이용하여 결정하였다. 분석 결과를 돼지 mtDNA 유전체 서열인 GenBank accession No. NC_000845(Lin 등, 1999)와 비교 검토하였 고, GenBank database에 등록하였다.

\section{PCR-RFLP 분석}

돼지 5 품종의 각 집단내 다형성 빈도를 조 사하기 위해 $N D 2$ 의 개시코돈을 결정하기 위하 여 제한효소 Tsp509I(NEB, UK)를 이용하여 증 폭산물을 절단하였다. 제한효소 처리를 위한 반응조건은 공급자의 manual에 따랐고, 효소 최적온도에서 overnight 반응하였다. 절단한 DNA
단편의 확인은 $3 \%$ agarose gel에서 전개하고, ethidium bromide 염색법으로 확인하였다.

\section{III 결과 및 고찰}

\section{1. 돼지 품종별 ND2 유전자 개시코돈}

mtDNA ND2 유전자의 개시코돈 서열에 대한 염기서열과 RFLP 분석을 수행하였다. 돼지 5품 종(Landrace, Large White, Duroc, Berkshire, Hampshire) 집단에서 개시코돈 서열상의 다형 성이 관찰되었고(Fig. 1), 다형성을 보이는 개체 를 DNA sequencing으로 확인한 결과 기존에 보 고된 $\mathrm{ND} 2$ 의 선택적 개시코돈 서열인 $\mathrm{ATA}$ 와 $\mathrm{ATT}$ 가 모두 출현하였으며 염기삽입/결실에 의 한 다형성은 관찰되지 않았다. 또한 미토콘드 리아 해독체계상 대다수의 단백질 유전자에서 출현하는 개시코돈 서열인 ATG 역시 확인되지 않았다. 품종별로 조사된 개체들에서 ATT/ATA 서열의 출현빈도를 Fig. 2에서 보는 바와 같다. PCR-RFLP 분석을 통하여 조사한 결과, Large White 76두 전 개체에서 ATA, Landrace 40 두에서는 ATT 서열로 확인되었으나, Duroc, Hampshire, Berkshire 품종에서는 ATT와 ATA의 2 종류의 개시코돈이 모두 확인되었고 출현 빈 도는 품종별로 다르게 나타났다(Table 1). 본 연구를 통해 확인된 $\mathrm{ND} 2$ 의 $\mathrm{AIC}$ 양상은 돼지 mtDNA ND2의 개시코돈이 ATA나 ATT라는 기 존의 보고들(Ursing과 Arnason, 1998; Lin 등, 1999; Kijas와 Andersson, 2001; Yang 등, 2003) 을 뒷받침 해주는 결과라 하겠다.

\begin{tabular}{|c|c|c|}
\hline & tRNA-Met & \\
\hline CNP & СTTCCCATACTAATAAATCCCATTATCTACACTACCCTTATCATAACAGTAATATCCGGA & Yang et al. (2003) \\
\hline Large White1 & 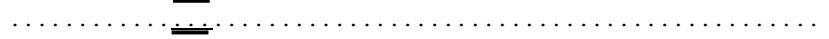 & Yang et al. (2003) \\
\hline Large White2 & 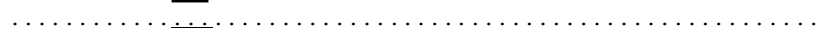 & This study \\
\hline Berkshire & 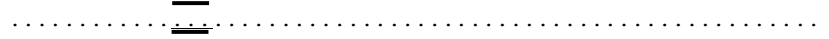 & This study \\
\hline Landrace1 & $\ldots \ldots \ldots \ldots \ldots \ldots \ldots \ldots \ldots \ldots \ldots \ldots \ldots \ldots$ & Yang et al. (2003) \\
\hline Landrace2 & $\ldots \ldots \ldots \ldots \ldots \ldots \ldots \ldots, \ldots \ldots$ & Lin et al. (1999) \\
\hline Hampshire & $\ldots \ldots \ldots \ldots \ldots \ldots \ldots \ldots \ldots \ldots \ldots$ & This study \\
\hline Duroc1 & 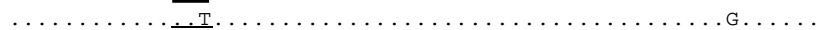 & Yang et al. (2003) \\
\hline Duroc2 & 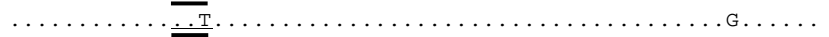 & This study \\
\hline
\end{tabular}

Fig. 1. A comparison of the part of mitochondrial fragment containing the initiation codon of ND2. The sequences underlined indicate the initiation codon of ND2 and dots are identical sequences to Chinese native pig breeds(CNP). 
Table 1. The frequencies of AIC patterns in pig breeds used in this study

\begin{tabular}{|c|c|c|c|c|c|c|c|c|c|c|}
\hline \multirow{2}{*}{$\begin{array}{l}\text { Sequence of } \\
\text { initiation codon }\end{array}$} & \multicolumn{2}{|c|}{ Berkshire } & \multicolumn{2}{|c|}{ Duroc } & \multicolumn{2}{|c|}{ Hampshire } & \multicolumn{2}{|c|}{ Landrace } & \multicolumn{2}{|c|}{ Large White } \\
\hline & $\mathrm{n}$ & $\%$ & $\mathrm{n}$ & $\%$ & $\mathrm{n}$ & $\%$ & $\mathrm{n}$ & $\%$ & $\mathrm{n}$ & $\%$ \\
\hline ATA & 62 & 91.9 & 10 & 21.3 & 6 & 60 & 0 & 0 & 76 & 100 \\
\hline ATT & 5 & 8.1 & 37 & 78.7 & 4 & 40 & 40 & 100 & 0 & 0 \\
\hline sum & 62 & & 47 & & 10 & & 40 & & 76 & \\
\hline
\end{tabular}

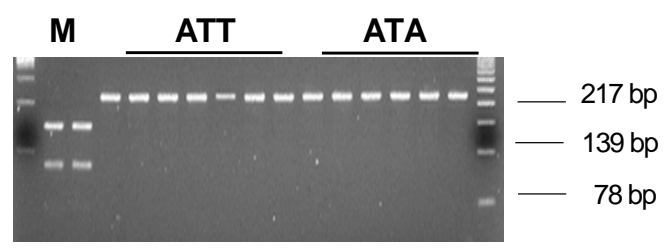

Fig. 2. A PCR-RFLP analysis of the initiation codon of mtDNA ND2. $\mathrm{M}$ is 100-bp DNA step ladder. Two types of initiation codon(ATT and ATA) in ND2 were shown. For the analysis, Tsp509I restriction enzyme(5'-AAT $\downarrow$ T-3') was used.

하지만, 선행연구 보고에서는 단지 $\mathrm{AIC}$ 의 출 현만을 보고하는데 그친 반면, 본 연구에서는 $\mathrm{AIC}$ 양상의 확인과 더불어 품종 집단 내에서 의 다형성도 확인하였다.

이 결과는 분석에 이용된 돼지 품종들 중에 서 Large White와 Landrace는 별개의 모계선조 에서 유래되었다는 것을 재차 확인하는 결과라 사료된다. Landrace의 경우는 유럽(덴마크)이 원 산인 것으로 알려져 있고, 본 연구에 이용된 개체들에서 공통적으로 ATT 유전자 서열을 갖 는 것을 고려하면, ND2 개시코돈에서 유럽 가 축돼지의 모계선조형은 ATT인 것으로 추정할 수 있다. 이러한 추정에 근거하여, Duroc에서 $\mathrm{ATT}$ 의 출현빈도가 $87.9 \%$ 로 높게 나타나는 것 은 Duroc이 유럽의 품종들을 이용하여 성립된 품종임을 확인하여 주는 결과라 하겠다.

특히, Yang 등(2003)의 보고에 따르면 mtDNA near complete 유전체 서열에 대한 분석에서 중국재래돼지 17 품종을 포함하는 계통유전 적 cluster 내에 Large White가 함께 포함된다고 보고하였고, Kim 등(2002)의 D-loop 분석결과에 서도 Large White 품종은 아시아 계열의 돼지
집단으로 분류된 것과 일치하는 결과라 하겠 다. Large White의 경우 품종 형성과정에서 18 세기경 유럽으로 전파된 중국돼지가 모계로 이 용된 것으로 보고되고 있다. 따라서 Large White에서 출현하는 개시코돈 ATA는 중국재래 돼지와 같은 모계선조인 아시아계열인 것으로 추정된다.

하지만, 본 연구결과에서 나타난 Berkshire와 Duroc, Hampshire 품종들에서 ATT/ATA의 집단 내 다형성은 이들 집단의 품종형성과정에서 적 어도 둘 이상의 모계 선조 집단에서 유래되었 거나, 품종형성과정에서 유입되었을 가능성을 시사해 주고 있다. Okumura 등(2001)은 mtDNA D-loop의 haplotype 분석에서 Berkshire, Duroc, Hampshire 등은 여러 가지 haplotype들로 구분 되고, Large White와 공통인 haplotype들이 관찰 된다는 점에서 이들 3 품종의 형성에서도 유럽 으로 전파된 중국돼지로부터의 모계 유입의 결 과로 추정된다. Duroc의 경우, D-loop 내 11-bp duplication motif의 출현 양상에서 크게 두 가지 아집단으로 구분되었고(조 등, 2003), D-loop 서 열에 대한 계통분석에서도 유럽과 아시아 계열 로 구분됨을 보고한 바 있다(Alves 등, 2003).

이상의 결과를 요약하면 유럽계열 품종으로 알려진 Landrace 전 개체와 Duroc의 $78.7 \%$ 에서 $N D 2$ 개시코돈으로 ATT 서열이 출현하였으며, 중국돼지들이 유입된 것으로 알려진 Large White 모든 개체들과 Berkshire 대다수(91.9\%) 에서 ATA 서열이 출현하는 것은, 가축화의 시 작은 아시아와 유럽에서 독립적으로 이루어졌 으며, 18 세기 이후 유럽에서 돼지 품종개량을 위하여 아시아 돼지를 유입했다는 가설을 지지 해 주고 있다. 돼지 미토콘드리아 ND2 개시코 돈의 다형성에 대한 분석을 각 지역에서 수집 
한 다양한 돼지 품종 집단으로 확대하여 분석 하고, 부계유전의 marker로서 $\mathrm{Y}$ 염색체의 유전 자 다형성을 조합한다면, 돼지 육종과정에서 모계 및 부계 유전자원의 유입 경로를 확인하 는 분자유전학적 척도로 이용될 수 있을 것으 로 사료된다.

$$
\text { IV 요 약 }
$$

다양한 포유동물의 미토콘드리아 유전자들에 서 선택적 개시코돈(AIC)들이 보고되었다. 본 연구는 돼지 5 품종에서 mtDNA ND2 유전자의 AIC 양상을 분석하였다. 두 종류의 AIC 서열들 이 발견되었고, 품종 집단간에서 각기 다른 출 현빈도를 보였다. ND2의 methionine codon으로 Large White와 Landrace는 각각 전 개체에서 $\mathrm{ATA}$ 와 ATT 서열로 확인되었다. 다른 3 품종 (Berkshire, Duroc, Hampshire)의 경우는 두 서열 이 모두 발생하였으며, 91.9, 21.3, $60.0 \%$ 의 빈 도로 ATA를 보였다. 기존의 연구들에 의하면 중국재래돼지들이 모두 개시코돈 ATA를 갖는 다고 보고되어 있다. 미토콘드리아 ND2 단백질 의 합성과정에서 AIC가 어떤 영향을 미치는지 는 설명할 수 없으나, 본 연구에서 나타난 AIC 다형성과 품종특이적인 분포양상은 돼지의 육 종에 있어 모계추적을 위한 분자적 표지인자로 서 이용될 수 있을 것을 사료된다.

\section{$\mathrm{V}$ 인 용 문 헌}

1. Alves, E., Ovilo, C., Rodriguez, M. C. and Silio, L. 2003. Mitochondrial DNA sequence variation and phylogenetic relationships among Iberian pigs and other domestic and wild pig populations. Anim. Genet. 34:319-324.

2. Anderson S., Bankier, A. T., Barrell, B. G., Bruijin, M. H. L., Coulson, A. R., Drouin, J., Eperon, I. C., Nierlich, C. D., Roe, B. A., Sanger, F., Schreier, P. H., Smith, A. J., Staden, R. and Young, I. G. 1981. Sequence and organization of the human mitochondrial genome. Nature. 290:457465.

3. Arnason, U. and Gullberg, A. 1993. Comparison between the complete mtDNA sequences of the blue and the fin whale, two species that can hy- bridize in nature. J. Mol. Evol. 37:312-322.

4. Bökönyi, S. 1974. History of Domestic Mammals in Central and Eastern Europe. Academiai Kiado, Budapest.

5. Brown, W. M., George, M. and Wilson, A. C. 1979. Rapid evolution of animal mitocondrial DNA. Proc. Natl. Acad. Sci. USA. 76:1967-1971.

6. Cann, R. L., Brown, W. M. and Wilson, A. C. 1984. Polymorphic sites and the mechanism of evolution in human mitochondrial DNA. Genetics. 325:31-36.

7. Coble, M. D., Just, R. S., O’Callaghan, J. E., Letmanyi, I. H., Peterson, C. T., Irwin, J. A. and Parsons, T. J. 2004. Single nucleotide polymorphisms over the entire mtDNA genome that increase the power of forensic testing in Caucasians. Int. J. Legal. Med. In press.

8. Giles, R. E., Blanc, H., Cann, H. M. and Wallace, D. C. 1980. Maternal inheritance of human mitochondrial DNA. Proc. Natl. Acad. Sci. USA. 77:6715-6719.

9. Giuffra, E., Kijas, J. M. H., Amarger, V., Carlborg, O., Jeon, J. T. and Andersson, L. 2000. The origin of the domestic pig: independent domestication and subsequent introgression. Genetics. 154:1785-1791.

10. Huang, Y., Shi, X. and Zhang, Y. 1999. Mitochondrial genetic variation in Chinese pigs and wild boars. Biochem. Genet. 37:335-343.

11. Janke, A., Magnell, O., Wieczorek, G., Westerman, M. and Arnason, U. 2002. Phylogenetic analysis of $18 \mathrm{~S}$ rRNA and the mitochondrial genomes of the wombat, Vombatus ursinus, and the spiny anteater, Tachyglossus aculeatus: increased support for the Marsupionta hypothesis J. Mol. Evol. 54:71-80.

12. Jones, G. F. 1998. Genetic aspects of domestication, common breeds and their origins. In: Ruvinsky, A., Rothschild, M. F. The genetics of the pig. 17-50.

13. Kijas J. M. H., Wales, R., Tornsten, A., Chardon, P., Moller, M. and Andersson, L. 1998. Melanocortin receptor $1(M C 1 R)$ mutations and coat color in pigs. Genetics. 150:1177-1185.

14. Kijas, J. M. H. and Andersson, L. 2001. A phylogenetic study of the domestic pig estimated from the near-complete mtDNA genome. J. Mol. Evol. 52:302-308.

15. Kim, K. I., Lee, J. H., Li, K., Zhang, Y. P., Lee, S. S., Gongora, J. and Moran, C. 2002. Phylogenetic relationships of Asian and European pig breeds determined by mitochondrial DNA D-loop sequence polymorphism. Anim. Genet. 33:19-25. 
16. Lin, C. S., Sun, Y. L., Liu, C. Y., Yang, P. C., Chang, L. C., Cheng, I. C., Mao, S. J. and Huang, M. C. 1999. Complete nucleotide sequence of pig(Sus scrofa) mitochondrial genome and dating evolutionary divergence within Artiodactyla. Gene. 236:107-114.

17. Lopez, J. V., Cevario, S. and O’Brien, S. J. 1996. Complete nucleotide sequences of the domestic cat(Felis catus) mitochondrial genome and a transposed mtDNA tandem repeat(Numt) in the nuclear genome. Genomics. 33:229-246.

18. Okumura, N., Ishiguro, N., Nakano, M., Katsuya, H., Matsui, A. and Sahara, M. 1996. Geographic population structure and sequence divergence in the mitochondrial DNA control region of the Japanese wild boar(Sus scrofa leucomystax), with reference to those of domestic pigs. Biochem. Genet. 34:179-189.

19. Ursing, B. M. and Arnason, U. 1998. The complete mitochondrial DNA sequence of the pig(Sus scrofa). J. Mol. Evol. 47:302-306.

20. Watanabe, T., Hayashi, Y., Ogasawara, N. and Tomita, T. 1985. Polymorphism of mitochondrial
DNA in pigs based on restriction endonuclease cleavage patterns. Biochem. Genet. 23:105-113.

21. Watanobe, T., Ishiguro, N., Nakano, M., Matsui, A., Hongo, H., Yamazaki, K. and Takahashi, O. 2004. Prehistoric Sado Island populations of Sus scrofa distinguished from contemporary Japanese wild boar by ancient mitochondrial DNA. Zoolog. Sci. 21:219-228.

22. Wilson, A. C., Cann, L., Carr, S. M., George, M. and Gyllensten, U. B. 1985. Mitochondrial DNA and two perspectives on evolutionary genetics. Biol. J. Linn. Soc. 26:375-400.

23. Yang, J., Wang, J., Kijas, J., Liu, B., Han, H., Yu, M., Yang, H., Zhao, S. and Li, K. 2003. Genetic diversity present within the near-complete mtDNA genome of 17 breeds of indigenous Chinese pigs. J. Hered. 94:381-385.

24. 조인철, 정용환, 정진관, 성필남, 김병우, 이정규, 전진태. 2003. Single stranded conformation polymorphism 분석에 의한 돼지 Duroc 품종의 미토 콘드리아 DNA 유전적 변이. 한국동물자원과학회 지. 45:911-916.

(접수일자 : 2004. 8. 30. / 채택일자 : 2004. 12. 1.) 